\title{
A Call for Authenticity : Audience Responses to Social Media Influencer Endorsements in Strategic Communication
}

\author{
Pöyry, Essi llona
}

2019

Pöyry , E I , Pelkonen , M , Naumanen , E \& Laaksonen , S-M 2019 , ' A Call for Authenticity : Audience Responses to Social Media Influencer Endorsements in Strategic Communication ' , International Journal of Strategic Communication , vol. 13 , no. 4 , pp. 336-351 . https://doi.org/10.1080/1553118X

http://hdl.handle.net/10138/327468

https://doi.org/10.1080/1553118X.2019.1609965

acceptedVersion

Downloaded from Helda, University of Helsinki institutional repository.

This is an electronic reprint of the original article.

This reprint may differ from the original in pagination and typographic detail.

Please cite the original version. 
This is an original manuscript (AAM) of an article published by Taylor \& Francis in International Journal of Strategic Communication, available in: https://www.tandfonline.com/doi/full/10.1080/1553118X.2019.1609965

Pöyry, E. I., Pelkonen, M., Naumanen, E. \& Laaksonen, S-M., (2019). A Call for Authenticity: Audience Responses to Social Media Influencer Endorsements in Strategic Communication. International Journal of Strategic Communication, 13(4), 336-351.

\title{
A Call for Authenticity:
}

Audience Responses to Social Media Influencer Endorsements in Strategic Communication

\begin{abstract}
Utilizing social media celebrities as a communication channel has become a strategic practice for many organizations. By using the concepts of celebrity endorsement and authenticity, the effect of celebrity and content characteristics on followers' attitudes towards the content and, in the case of sponsored content, purchase intentions are scrutinized. 592 Instagram followers of 45 celebrities responded to a survey on nine photos of the celebrities. The results show that both the perceived authenticity and attractiveness of the celebrity are positively related with photo attitudes, but only authenticity has an effect on purchase intentions. Photos of social media influencers, people who have become famous through social media, increase purchase intentions more than photos of general celebrities. Congruence between the photo and the celebrity has the strongest positive effect on photo attitudes and purchase intentions. Sponsored photos are less favorably perceived than nonsponsored photos, but, among sponsored photos, sponsor disclosure has no effect on purchase intentions. The perceived authenticity of both the celebrity and her content is said to explain favorable audience perceptions. The findings imply that organizations should seek authentic matches between their message and the endorsing celebrity and that the content should align with the usual style of the celebrity.
\end{abstract}

Keywords: Instagram, celebrity endorsement, authenticity, sponsor disclosure, influencer marketing, social media influencer 
A Call for Authenticity:

Audience Responses to Social Media Influencer Endorsements in Strategic Communication

As social media have matured, the relative influence of one's peers is decreasing, while celebrities are gaining ground, particularly in certain social media channels such as Instagram and Snapchat (Chaffey, 2017). Indeed, both general celebrities (athletes, actors, etc.) gone digital and so-called social media influencers (people who have become famous via social media) attract an increasing number of followers (Abidin, 2015; Giles, 2017; Kapitan \& Silvera, 2016; Marwick, 2015), thus increasing their share of voice.

Communication professionals and marketers have realized the potential of collaborating with these celebrities, and consequently the terms influencer communication and influencer marketing have been widely embraced to refer to the appearance of branded goods in the celebrities' social media channels (Sudha \& Sheena, 2017).

Not only information about products and services, but also ideas, ideologies and public information can be communicated through the channels of social media celebrities to very specific, and often devoted, audiences (Khamis, Ang \& Welling, 2017; Senft, 2008). Thus, for organizations, social media celebrities provide a new channel through which they can purposefully communicate to reach their goals (Hallahan, Holtzhausen, van Ruler, Verčič, and Sriramesh, 2007) and to to frame topics identified as strategic and substantial (Zerfass, Verčič, Nothhaft \& Werder, 2018). The potentially great reach and impact of social media celebrities, as well as their lending of symbolic meaning and reputation (McCracken, 1989; Aula \& Heinonen, 2016), can be crucial to successful participation in the ongoing process of meaning construction (van Ruler, 2018).

The idea of using celebrities to enhance an organization's promotional message is nothing novel. Celebrity endorsements have typically been studied in branding and advertising research (e.g., Erdogan, 1999; Kamins, 1990; Keel \& Nataraajan, 2012; Ohanian, 
1990). However, the current practice of influencer communication challenges many of the basic tenets of the traditional celebrity endorsement model. Social media celebrities come from a much wider spectrum of people than the celebrities who have traditionally been chosen for celebrity endorsement campaigns. Many of the most influential social media celebrities are known by a very small share of people in a given region while general celebrities are usually known by relatively many (Abidin, 2015). Past research has studied celebrity endorsements extensively as a part of the marketing process (e.g., Hsu \& McDonald, 2002; Ohanian, 1990; Silvera \& Austad, 2004), but research in the area of strategic communication remains scarce, and thus we lack understanding of the ways in which celebrity endorsement can be used to advance the survival and sustain the success of an organizational entity (Zerfass et al., 2018).

This study investigates the effectiveness of the content that social media celebrities produce by using the concept of authenticity. Authenticity is a multifaceted construct that is often linked to attributes such as genuinity, truthfulness and originality (Molleda, 2010), all of which are central in effective celebrity endorsement in social media. We scrutinize authenticity as a perceived feature of a celebrity but also through attributes of their social media content that attempt to manifest authenticity. Empirically, we focus on photos that celebrities have posted on Instagram, a popular social media channel. We use a survey method to study the effect of celebrity characteristics, type of celebrity, congruence between a photo and the celebrity's style, as well as photo sponsorship and sponsor disclosure on the followers' attitudes towards the photo and purchase intentions. The respondents are sampled among the followers of a number of different celebrities, which increases the generalizability and validity of the findings.

In the following sections, we will first introduce and discuss celebrity endorsement as a strategic communication practice and then move on to formulate our hypotheses based on 
existing research. Then, we will explain our methodological approach and the regression models, and present the findings of the statistical analyses. Finally, we will discuss the findings in connection with strategic communication literature and provide future research avenues and implications for practitioners.

\section{Celebrity endorsement as a strategic and authentic communication practice}

Celebrity endorsement is a well-known marketing communication technique that allows marketers to take advantage of celebrities promoting their products (Erdogan, 1999). A celebrity endorser can be an artist, a movie star, or any other public figure who uses their recognition and image to make paid product endorsements (McCracken, 1989). Research widely suggests that celebrity endorsements have positive effects on brand recall, brand attitudes, purchase decisions, product sales, and stock value (Djafarova \& Rushworth, 2017; Elberse \& Verleun, 2012; Kamen, Azhari \& Kragh, 1975; Kamins, 1990; Mathur, Mathur \& Rangan, 1997). According to McCracken (1989) and Roy (2016), the effectiveness of a celebrity endorsement is produced by a transfer of symbolic meanings; the culturally-relevant symbolic meanings first reside in the celebrity, and, through the endorsement, they transfer to a product, and, from the product to the consumer. Recently, similar approaches have been adopted beyond marketing in areas such as CSR communication, lobbying, and strategic communication (e.g., Fitch, 2017; Park \& Cho, 2015).

Several aspects differentiate celebrity endorsement in social media from those in traditional media. First, social media blends the content of one's peers and the content of celebrities, which can increase the attention that the celebrities receive as opposed to traditional advertisements (Giles, 2017; Kapitan \& Silvera, 2016). Moreover, in social media, the user has explicitly decided to follow the celebrity and is able to interact with him or her (Khamis et al., 2017; Senft, 2008), and the content is distributed and usually also created by the celebrity (Abidin, 2015; Kapitan \& Silvera, 2016). A celebrity endorser traditionally 
works only with a few select brands (Hsu \& McDonald, 2002), but many social media influencers make their living from sponsored endorsements with various partners (Colliander $\&$ Erlandsson, 2013). These factors have arguably increased the rate and changed the nature of sponsored product endorsements. Simultaneously, being a celebrity in social media is a technosocial practice. Social media celebrities work in an "industrial conjuncture" formed by the social media platform (Hou, 2018; Thomas, 2014); they must constantly negotiate between the pressures of being interesting and credible, as well as economically profitable, and assimilate to the changing technological affordances of the platform.

These negotiations connect to authenticity of self-presentation (see Abidin \& Ots, 2016; Audrezet, de Kerviler \& Moulard, 2018), a property of communication that has gained interest in areas such as advertising, communication studies, marketing, and public relations (e.g., Audrezet et al., 2018; Brown, Kozinets \& Sherry, 2003; Molleda \& Roberts, 2008). Authenticity has been identified as an important but also an elusive concept: the term is used to describe a variety of objects and behaviors, and is often perceived differently by different parties. In sociology and social psychology, the concept relates to self-presentation and conceptions of the self, meaning "the feeling and practice of being true to one's self or others" (Vannini \& Franzese, 2008, p. 1621). Authenticity can thus be understood through attributes such as sincerity, genuineness, truthfulness, and originality (for a review of different definitions, see Molleda, 2010). Similar conceptions have been presented in celebrity studies, in which authentic celebrity brands are seen to appear genuine in their consumer relationships when they behave according to their values (Ilicic \& Webster, 2016; Moulard, Garrity \& Rice, 2015).

Authenticity is considered to boost message effectiveness as it allows the recipient to identify with the message and the sender (Brown et al., 2003). In strategic corporate communications, it is argued that authenticity helps to provide effectiveness and credibility as 
it allows organizations to operate and take a stance in open, undefined areas as opposed to shaping audience perceptions within narrowly defined contexts (Molleda \& Roberts, 2008). Authenticity is, however, not a straightforward attribute, in particular for a corporate actor, whose communications always come with a less or more hidden agenda (Gilmore \& Pine, 2007). Molleda (2010) reminds us that the context of communication and the technology used to communicate affect what the recipient perceives to be authentic; various cues can be used to craft an authentic identity and voice, which are then subjectively judged and negotiated by and with the audience (Beverland \& Luxton, 2005; Grayson \& Martinec, 2004; McLeod, 1999). Arguably, as sociotechnical systems, social media have many contextual features that allow (or deny) authentic communications between an organization and its stakeholders. In the case of celebrity endorsements, social media provides a way for brands to be presented authentically through the celebrity's own words, pictures or videos rather than through television commercials, billboards or magazine advertisements.

From the perspective of authentic communication and its strategic planning, celebrity endorsements lead to the existence of two distinct but interdependent relationships: one between the organization and the celebrity, and another between the celebrity and his or her audience. Macnamara and Zerfass (2012) argue that there is a lack of general knowledge regarding the ways in which organizations seek to utilize social media in their strategic communication, particularly because there is a clash between strategic management practices and the online philosophies of openness, participation and democratization. The dilemma becomes even more evident when a social media celebrity participates in the framing of the message; the organization should strategically decide with whom it can and should cooperate with, and in what ways the delivery of the messages can be outsourced and opened to external communicators. At the same time, social media celebrities themselves are constantly negotiating between their own credibility and the sponsored content they post (Abidin \& Ots, 
2016; Audrezet et al., 2018). Partly because of this problem, celebrities seek authenticity by “staging" it (Hou, 2018; Thomas, 2014). They purposefully share intimate and private photos, interact with their followers and strive for a sense of equality and commonality (Abidin, 2015). All these considerations make organizations' collaboration with social media celebrities more complex because it incorporates several levels of strategic considerations concerning multiple actors.

Next, we utilize the ideas presented above to make hypotheses regarding the effect of celebrity and photo characteristics on two outcomes of integrated communication processes: photo attitude and purchase intention. Message attitude is an important goal of communication (Hovland, Janis \& Kelley, 1953) and of strategic communication (de Vries, Gensler \& Leeflang, 2012; Wang, Qiao \& Peng, 2015), while purchase intention and purchases are currently the most common organizational goals of sponsored social media content — and therefore reasonably operationalized for the study of actual social media content. By and large, we expect that the effects on photo attitudes are parallel with purchase intentions (Spears \& Singh, 2004; Wang et al., 2015), despite some inconsistencies in the research evidence (cf. Till \& Busler, 1998).

\section{Celebrity characteristics as predictors of photo effectiveness}

Celebrity endorsement literature has proposed several positive source characteristics that explain the influence of a celebrity endorser. The most well-known and repeatedly-used model was developed by Roobina Ohanian (1990), and is composed of three main dimensions: trustworthiness, expertise, and attractiveness. Even though these dimensions have been acknowledged to play a role in celebrity endorsement, research is ambiguous regarding their relative importance (cf. Deshpandé \& Stayman, 1994; Ohanian, 1990; 1991; Pornpitakpan, 2004). Other studies have emphasized the mediating role of social relationships and (para)social identification with the endorser, particularly in connection to 
social media celebrities (Gong \& Li, 2017; Ilicic \& Webster, 2016; Jin, 2018; Labrecque, 2014). The main claim put forward by these studies is that celebrity endorsements are effective because they facilitate a feeling of belonging and social connectedness with their audiences.

While various studies investigate the effectiveness of celebrity endorsements (for a meta-analysis, see Knoll \& Matthes, 2016), the exploration of social media celebrities, particularly in the context of visual platforms such as Instagram, has only recently begun to interest researchers (e.g., Djafarova \& Trofimenko, 2018; Gong \& Li, 2017; Phua, Lin \& Lim, 2018). It is reasonable to expect differences in the dynamics in which the effectiveness of celebrity attributes is played out. For example, instead of being a meritocratic attribute, expertise in social media is a cumulative construct based on the thematic branding and communication strategies pursued by the celebrity (Tolson, 2013). Therefore, rather than investigating the traditional celebrity endorser characteristics, we are interested in studying factors that are expected to be particularly relevant in social media: perceived authenticity and attractiveness.

Authenticity. As discussed above, authenticity is important for the branding of social media celebrities, as well as for corporate branding more generally. Studies have explored the effects and outcomes of brand authenticity, showing, for example, that brand authenticity positively impacts brand trust (Schallehn, Burmann \& Riley, 2014) and consumers' behavioral intentions (Fritz, Schoenmueller \& Bruhn, 2017). Further, Ilicic and Webster (2016) showed that the perceived authenticity of a celebrity was a more important predictor of consumers' purchase intentions than familiarity with the celebrity. It is assumed in the context studied - Instagram photos of social media celebrities — that authenticity is a particularly important attribute as the channel is abundant with sponsored endorsements and other advertisements (Audrezet et al., 2018). Therefore, we suggest the following hypothesis: 
H1. Perceived authenticity of a social media celebrity is positively related to followers' (a) photo attitudes and (b) purchase intentions.

Attractiveness. Research has traditionally assumed that an individual's physical attractiveness has a positive impact on how influential he or she is (Chaiken, 1979). With regards to celebrity endorsement, the evidence is inconsistent. Kahle and Homer (1985) and Pornpitakpan (2004) claim that a celebrity's attractiveness increases message recipients' purchase intentions, while Ohanian (1991) and Silvera and Austad (2004) found that attractiveness was not a significant determinant of purchase intentions. However, particularly within certain themes and topics, social media is highly focused on users' looks and appearances. Djafarova and Rushworth (2017) found that, for some users, the visual attractiveness and the quality of photos is one of the main reasons to follow a celebrity on Instagram. It therefore stands to reason that celebrity attractiveness has a positive effect on photo attitudes and purchase intentions. Based on these considerations, we hypothesize:

H2: Perceived attractiveness of a social media celebrity is positively related to followers' (a) photo attitudes and (b) purchase intentions.

Celebrity type. Compared to the traditional forms of media or the traditional logic of the entertainment industry, social media has created various opportunities for individual actors to gain fame (Labrecque, Markos \& Milne, 2011; Khamis et al., 2017). Various terms have been used to describe people who have become famous through social media: microcelebrity (Senft, 2008; Marwick, 2013), the instafame (Marwick, 2015) and vlogger celebrity (Hou, 2018), for instance. In this study, we use the term social media influencer (Abidin, 2015; Khamis et al., 2017) to emphasize the origin of the fame without restricting the person's area of influence to any specific channel or taking a stand on the size of the 
influence. Several authors suggest that these persons influence consumer preferences more than traditional advertising or widely-known general celebrities, due to their higher authenticity and credibility (de Vries et al., 2012; Giles, 2017; Djafarova \& Rushworth, 2017).

In this study, we compare the effectiveness of social media influencers to so-called general celebrities, such as actors, athletes and models. Social media influencers often represent different styles and demographics than general celebrities (Marwick, 2015), and their communication style is usually more personal and direct (Keel \& Nataraajan, 2012). These differences are also reflected in how consumers identify with them and react to their social media content. Giles (2017) showed that social media influencers achieve an important role as legitimizing agents within their field through so-called micro-celebrity practices. Djafarova and Rushworth (2017) suggest that social media influencers have a particularly strong influence on the purchase behavior of young female users in Instagram. Further, researchers have identified a mediating effect of social identification with the endorser (Jin \& Phua, 2014; De Veirman, Cauberghe \& Hudders, 2017), which is arguably higher in the case of social media influencers due to the close relationship they often have with their followers (see also Gong \& Li, 2017; Verhellen, Dens \& De Pelsmacker, 2013). Therefore, we hypothesize:

H3: Compared to general celebrities' photos, social media influencers' photos are more positively related to followers' (a) photo attitudes and (b) purchase intentions.

\section{Photo characteristics as predictors of photo effectiveness}

Product-celebrity congruence. One aspect of authenticity is the practice of being consistent in one's behavior and true to one's character (e.g., Vannini \& Franzese, 2008; Marwick, 2013). In the context of celebrity endorsement, the assessment of such consistency 
is expanded to the relationship between the celebrity and the product being endorsed. Advertising research has repeatedly found that a celebrity endorsement is effective when there is a good fit, or congruence, between the endorser and the product (Kahle \& Homer, 1985; Kim \& Na, 2007; Kamins, 1990; Till \& Busler, 1998). For example, a tennis player is a good endorser of tennis rackets. Research also shows that lack of congruence is not only a missed opportunity but can also have negative effects on brand recall (Evans, 1988). Moreover, a lack of a relationship between the endorser and the product leads consumers more likely to believe that the endorsement was bought than in the case of appropriate product-celebrity pairs (Silvera \& Austad, 2004). Perceived congruence has been found to be in effect even when a consumer is unfamiliar with the endorser or the product (McCormick, 2016). Further, a recent study of celebrity endorsements on Instagram showed that mere image congruence between a celebrity and a product improved consumer responses (Phua et al., 2018). In other words, the product does not need to be directly associated with the celebrity's profession, for example, but it needs to fit an abstract idea of what the celebrity is like and what his or her style is. Based on these considerations, we hypothesize:

H4: Perceived congruence between a social media celebrity's style and her photo is positively related to followers' (a) photo attitudes and (b) purchase intentions.

Sponsor disclosure. There is an increasing call for disclosures of sponsored product endorsements in social media and product placements in entertainment media among both consumers and policy makers (Cain, 2011; Dekker \& Reijmersdal, 2013). There is some research evidence that doing so would also be preferable from the organization's perspective. Nebenzahl and Secunda (1993) found that consumers have positive attitudes towards product placements when they are transparent. Consumers may even prefer sponsored online content over alternative forms of on-screen advertisements due to their unobtrusive nature (Gupta \& 
Gould, 1997; Nelson, Keum \& Yaros, 2004; Tutaj \& van Reijmersdal, 2012). In the case of sponsored product endorsements in blogs, research shows that consumers are indifferent as to whether the blogger has received cash or a product discount for an endorsement ( $\mathrm{Lu}$, Chang \& Chang, 2014). Some studies, on the other hand, show that disclosing a sponsorship causes consumers to develop distrustful beliefs about the content (Boerman, Willemsen \& Van Der Aa, 2017).

In many cases, however, the consumer is unable to know if a celebrity has received a compensation for endorsing a product, and it is suggested that there are numerous undisclosed sponsored endorsements (cf. Roettgers, 2016). Thus, if a person is unaware that a product endorsement in social media has been sponsored, he or she may easily perceive it as word-of-mouth communication (WOM). WOM is known to be highly influential over the basis on which consumers make purchase decisions (e.g., Cheung \& Thadani, 2012; Erkan \& Evans, 2016) so it can be argued that consumers are more strongly influenced by such endorsements if sponsors are left undisclosed. We therefore posit the following hypothesis:

H5: Compared to sponsored photos, a non-sponsored photo is more positively related to followers' photo attitudes.

H6: Compared to sponsored photos that reveal the sponsor, a sponsored photo that does not reveal the sponsor is more positively related to followers' purchase intentions. 


\section{Method}

\section{Celebrity survey}

The social media celebrities for the study were chosen from a Finnish Instagram marketing agency's influencer network. The agency is focused on hosting influencers who post mainly fashion, beauty, home décor and family-themed photos. The agency collaborates with celebrities who have at least 2000 followers. For the purpose of this study, two persons who work at the agency and know the celebrities well categorized them into general celebrities (actors, models, etc.) and social media influencers (bloggers, Instagram stars, etc.). In many cases, the social media influencers have gained fame beyond social media but the rule of the categorization was the origin of their fame.

The survey was sent to 75 social media celebrities by email in November 2016. The celebrities were asked to answer questions regarding each of their nine latest photos, excluding the very newest photo (for which the number of likes was still likely to change). Among other things, we asked if the photos had been a part of a commercial collaboration (i.e., if they had been sponsored) either through the agency or otherwise. The researchers collected what information they could via Instagram (number of followers, number of likes per photo).

45 social media celebrities in all responded to the survey (response rate $60 \%$ ). $93 \%$ of the respondents were women, and $7 \%$ were men. The distribution largely aligns with the gender distribution of all the celebrities the agency cooperates with. The average age of the respondents was 30.1 years $(S D=6.8)$. Their average number of followers was $23,997(S D=$ $35,432)$. On average, the photos within the sample had attracted 1841 likes each $(S D=3203)$. Of the celebrities, $24 \%$ were categorized as general celebrities and $76 \%$ social media influencers. The average number of followers was $43,122(S D=38,854)$ for general 
celebrities and 17,810 $(S D=31,950)$ for social media influencers, and the difference is statistically significant $(F(1,43)=4,487, p<.05, N=45)$.

Of the photos, $75.8 \%$ had not been sponsored, $16.3 \%$ had been sponsored but with the sponsor not explicitly disclosed, and $7.9 \%$ had been sponsored with the sponsor disclosed. As signs of disclosure, we accounted for texts and hashtags such as "ad", "collaboration", "sponsored", either in Finnish or in English (at the time of the study, Instagram did not allow the marking of a sponsored photo as an application feature on top of the photo). There was no significant difference in photo sponsorship $\left(X^{2}(1)=.305, p=.581, N=405\right)$ and, among sponsored photos, sponsor disclosure between general celebrities and social media influencers $\left(X^{2}(1)=1.476, p=.224, N=98\right)$. Figure 1 presents three example photos that were part of the sample. Most of the photos in the sample followed similar aesthetics.

FIGURE 1 HERE

\section{Follower survey}

A follower survey was conducted between November 2016 and February 2017. Using the Instagram inbox, a survey was sent to 90 randomly selected followers of each social media celebrity who had responded. The same nine photos were presented to the respondents who were asked to answer questions about the celebrity and each of the nine photos. For each photo, the survey showed the name of the Instagram account, the photo and its caption, and the number of likes (as shown in example photos in Figure 1). With the survey, we measured on a 1-7 Likert-type scale the followers' perceptions about celebrity authenticity and attractiveness (Vannini \& Franzese, 2008; Ilicic \& Webster, 2016; Ohanian, 1990), photocelebrity congruence (Kim \& Na, 2007), photo attitudes (Silvera \& Austad, 2004) and purchase intentions invoked by the photos (Erkan \& Evans, 2016). The item wordings were made to fit the specific research context. Cronbach's alphas were computed to evaluate the construct reliability of the scales. All varied between .850 and .942 , indicating good 
reliability (Malhotra, Birks \& Wills, 2012). See Table 1 for a summary of the survey constructs and items.

The 4050 follower surveys attracted responses from 592 respondents (response rate $13.4 \%)$. The average age of the respondents was 25.6 years $(\mathrm{SD}=8.8), 88 \%$ were women, and $12 \%$ men. According to Omnicore (2017), approximately $68 \%$ of Instagram users are women. Nevertheless, as most of the celebrities in the sample were women, the overrepresentation of women in the follower sample was expected.

\section{TABLE 1 HERE}

We created two analytical models to answer the research questions: a model explaining followers' photo attitudes using all the photo evaluations $(N=5119)$ and a model explaining followers' purchase intentions using only those evaluations that concerned sponsored photos $(N=1312)$. We used hierarchical multiple regression to model the data, which met the assumptions for the analysis. Neither non-linearity nor heteroscedasticity was identified in the residuals of the research variables (Hair, Anderson, Tatham \& Black, 1998). When testing for multicollinearity, no problems arose based on Tolerance and VIF statistics (thresholds $>.10$ and $<10$, respectively) (Hair et al., 1998).

\section{Results}

Followers' photo attitudes were modelled first (see Table 2). In the first step of the model, the number of likes a photo had received (logarithmic scale) was included in the model as a control variable. The results indicate that the number of likes had a small positive relationship with followers' photo attitudes $(\beta=.068, p<.01)$. Then, in the second step, celebrity-related variables were included. These variables improved $R^{2}$ by $16.1 \%$. Authenticity and attractiveness both had a positive effect $(\beta=.227, p<.01, \beta=.240, p<.01$, respectively). Hence, $\mathrm{H} 1 \mathrm{a}$ and $\mathrm{H} 2 \mathrm{a}$ are supported. Celebrity type also had a positive, yet small, relationship with photo attitudes, which was higher for social media influencers' 
photos $(\beta=.029, p<.05)$. This finding provides support for H3a. In the third step, photorelated variables were included in the model. Photo-celebrity congruence related strongly with photo attitudes $(\beta=.529, p<.01)$, which indicates support for H4a. Finally, the results suggest that photo sponsorship had a negative relationship with photo attitudes $(\beta=-.056, p<$ $.01)$. This supports H5; non-sponsored photos are perceived more favorably than sponsored photos. Including the photo-related variables in the model diluted the effect of the celebrity type, which suggests that, finally, there was no direct relationship between celebrity type and photo attitudes. Thus, $\mathrm{H} 3 \mathrm{a}$ is not supported. The final model explained $41.5 \%$ of the variability of photo attitude.

\section{TABLE 2 HERE}

With regards to purchase intention, we included only sponsored photos in the model (see Table 3). First, the results suggest that there was no significant relationship between the number of likes and followers' purchase intentions. In the second step, photo-related variables were included in the model, which improved $R^{2}$ by $11.6 \%$. Both perceived authenticity and attractiveness had a positive relationship with purchase intentions $(\beta=.254$, $p<.01$ and $\beta=.118, p<.01$, respectively), thus supporting $\mathrm{H} 1 \mathrm{~b}$ and $\mathrm{H} 2 \mathrm{~b}$. Social media influencers' sponsored photos were more positively related with purchase intentions than general celebrities' sponsored photos $(\beta=.136, p<.01)$, which supports H3b. In the third step, photo-celebrity congruence had the strongest relationship with purchase intentions $(\beta=$ $.458, p<.01)$, meaning that $\mathrm{H} 4 \mathrm{~b}$ is supported. Sponsor disclosure did not have a significant relationship with purchase intentions. H6 is thus not supported. Finally, including the photorelated variables in the model diluted the direct effect of perceived attractiveness, and $\mathrm{H} 2 \mathrm{~b}$ is therefore not supported. The final model accounted for $29.4 \%$ of the variability of purchase intention.

TABLE 3 HERE 
To further elaborate on the relationship between photo sponsorship, celebrity type, photo attitude and purchase intention, Figures 2 and 3 illustrate their mean differences. As shown, photo attitude remained the same for social media influencers regardless of whether a photo was sponsored or not, while general celebrities' non-sponsored photos were more favorably perceived than their sponsored photos. Purchase intention was consistently higher in case of social media influencers' sponsored photos than general celebrities' sponsored photos, regardless of whether the sponsor was disclosed. The followers still considered sponsor-disclosing photos more commercial than those that did not disclose the sponsor, suggesting that they paid attention to the disclosure. Measured with a statement "I think commercial content is central in this photo", the sponsor-disclosing photos were more highly rated $(M=5.67, S D=1.68)$ than photos that did not disclose the sponsor $(M=4.82, S D=$ 1.79) $(F(1,1332)=64,832, p<.01, N=1334)$. It is also worth noting that perceived authenticity was not dependent on celebrity type. Both general celebrities $(M=5.61, S D=$ $1.05)$ and social media celebrities $(M=5.36, S D=1.15)$ were perceived as authentic $(F(1,586)=3,778, p=.052, N=588)$.

\section{FIGURES $2 \& 3$ HERE}

\section{Discussion}

As with many previous studies, we found that certain celebrity characteristics have an effect on how favorably the audience perceives them and the endorsements they make. Perceived authenticity was found to have a positive effect on both photo attitudes (all photos) and purchase intentions (sponsored photos). Attractiveness, on the other hand, had a positive effect on photo attitudes, which seems reasonable considering the large role of visual elements and appeal in Instagram. Attractiveness did not, however, have any effect on followers' purchase intentions, which contradicts many celebrity-endorsement studies 
(Pornpitakpan, 2004; Till \& Busler, 1998). The accentuated effect of authenticity on purchase intentions supports the idea that, in order to be effective, the sponsored content that a celebrity posts should align with his or her ideals and values. Therefore, in accordance with existing studies on the relevance of authenticity for social media celebrities (e.g., Thomas, 2014; Audrezet et al., 2018), our results highlight the importance of the 'aura of authenticity' possessed or performed by the celebrity.

Second, congruence between the style of the photo and the celebrity had the strongest positive relationship with photo attitudes and purchase intentions, which is in line with previous research findings (Keel \& Nataraajan 2012; Knoll \& Matthes, 2017; McCormick, 2016; Phua et al., 2018). Photo-celebrity congruence may be the dimension that captures the essence of photo authenticity and makes the photo genuine and credible. The follower knows what kind of content the celebrity has posted before, so if a new photo is not consistent with that style, he or she reacts negatively. Further, observations on congruence are in line with the existing literature that emphasizes authenticity both for celebrity brands (Ilicic \& Webster, 2016) and brands in general (Molleda, 2010; Molleda \& Roberts, 2008): communication is more effective when the image of the celebrity also remains consistent with regard to the products endorsed. The congruence effect is present not only for sponsored content, but also for the full set of images tested in the attitude model, which, together with the large effect size, indicates that congruence is an important aspect when followers evaluate visual messages.

Photo sponsorship had a negative effect on photo attitude (both sponsor-disclosing and non-disclosing photos). This is unsurprising given the positive attitudes that consumers have towards spontaneous and real WOM messages (Cheung \& Thadani, 2012; Erkan \& Evans, 2016). However, an interesting finding is that, among the sponsored photos, disclosing the sponsor had no statistically significant effect on purchase intentions, as 
indicated by our second model. This finding is supported by Nebenzahl and Secunda (1993), who argue that there are no strong objections when product placements are disclosed as advertisements. Lu and colleagues (2014) suggest a similar effect in the case of sponsored blog posts. According to the present study, the same applies to followers of celebrities on Instagram - neither the celebrity nor the sponsor benefits from not disclosing the sponsor because purchase intentions were not affected.

Our results highlight the effectiveness of social media influencer endorsements. Traditionally, celebrity endorsement literature has studied the effect of well-known big stars (Erdogan, 1999), but, in the context of social media, regular-seeming people can also hold celebrity status. Thus, the opportunities for influence have become more fragmented. In the current study, sponsored photos of social media influencers elicited higher purchase intentions than sponsored photos of general celebrities. With regards to photo attitudes, the celebrity type did not have an effect, indicating that general celebrities' photos also contain interesting content. The findings suggest, thus, that when it comes to behavioral intentions, social media influencers' endorsements are more relevant than general celebrities' endorsements, as also suggested by Djafarova and Rushworth's (2017) interview study. The results also lead us to believe that the influence of social media influencers is based on other factors than what existing research has determined in the context of traditional celebrities and mass media (cf. Ohanian, 1991).

Moreover, as social media influencers arguably have a closer relationship with their followers as their fame has arisen from social media, the effectiveness of their endorsements may also be based on the effectiveness of WOM communications (Cheung \& Thadani, 2012; Erkan \& Evans, 2016; Jin, 2018). Followers may regard social media influencers' sponsored endorsements as more like peer endorsements, which increases their effectiveness. The fact that most social media influencers are rarely featured in mass media might accentuate this 
perception (Labrecque, 2014). It thus seems that social media influencers might enable identification more easily than general celebrities (Gong \& Li, 2017; Jin \& Phua, 2014) and that the transfer of desired attributes is more effective for the messages endorsed by social media influencers rather than general celebrities (McCracken, 1989; Roy, 2016). These observations make social media influencers attractive for strategic communication, them being 'people like me' readily present in the digital environments in which the stakeholders spend their time.

\section{Limitations and future research}

While the findings of this study carry several implications, some limitations need to be addressed. First, there is not yet an established framework to measure the influence of social media celebrities, nor influence in social media more generally. In this study, we followed recent scholarship on social media celebrities and focused on the source characteristics of authenticity instead of relying on classical celebrity endorsement models (e.g., Ohanian, 1990). Our results show that the characteristics selected are significant determinants of self-reported photo attitude and purchase intention. Nevertheless, we suggest that more research and scale development is needed in order to define the characteristics that influence followers of social media celebrities, and followers of social media influencers in particular. It also remains unclear how the perceptions of social media influencers develop in the future if they are featured in mass media more often, reach even more followers and start to resemble general celebrities.

Further, one dependent variable in this study was purchase intention, and it is clear that this variable does not equal realized purchase decisions, even if the former often has predictive power over the latter (De Cannière, De Pelsmacker \& Geuens, 2009). So, the findings regarding purchase intentions need to be interpreted with care. Future research should study real purchase decisions, for example by utilizing the specific discount codes that 
social media celebrities often use to track consumers' purchases. Moreover, strategic communication research could benefit from other dependent variables as well, such as more general conceptualizations of message effectiveness and comprehension. Such approaches would also account for other than commercial contexts, for example political or health communication. Recent developments in influencer collaboration practices give reason to expect that social media celebrities will be used more frequently in non-commercial areas of communication in the future. However, for this study, we chose to focus on purchase intention because it fits to the current mainstream practices of celebrity endorsement in social media.

As the present study did not account for the visual content of the photos studied, future research could focus on the content of the visual messages in greater detail. Furthermore, after the completion of the survey, a feature called "Stories" (short videos available only for a limited time) became popular on Instagram, and future research should consider the effect of such content as well. Further, as product endorsements have become more commonplace in social media, research should explore the accepted rate of sponsored content in one celebrity's social media feed. Does the effectiveness of an endorsement decline as more sponsored endorsements appear and does photo-celebrity congruence, for example, alleviate this effect?

\section{Contributions and implications for strategic communication}

This study contributes to our understanding on the effectiveness of celebrity endorsement and influencer collaboration. The findings illustrate the change in how influence ramifies in our mediated society; social media celebrity endorsements are a prime example of a novel mechanism to promote products, worldviews and ideologies in contexts that were originally considered and promoted as spaces for genuine peer communication and empowerment (e.g., Borchers, 2016; Curran, 2012). Several contributions to the area of 
strategic communication can be identified. First, we found that social media influencers' photos are more influential than general celebrities' photos when it comes to purchase intentions evoked. It is assumed that the social media influencers generate a greater sense of social identification (Djafarova \& Rushworth, 2017; Gong \& Li, 2017), and thus they gain more defined and relevant followers than general celebrities, which improves the impact of their endorsements. This means organizations will most likely benefit from strategic communication collaboration with social media influencers.

On the other hand, social media influencers typically have fewer followers than general celebrities (Hartmans, 2018), so organizations need to collaborate with a greater number of social media influencers in order to reach as large of an audience. Moreover, while social media influencers have relatively higher influence among their own social media followers, it is likely that their influence is significantly lower among the general population, who might not even recognize them. Therefore, if the company intends to use a celebrity endorser in mass media advertisements in addition to sponsored social media photos, general celebrities (with a good message-celebrity match) can be better choices as they are known to a wider population. Our results indicate, however, that social media influencer endorsements work effectively if aimed to reach specific stakeholders for a given strategic communication goal.

Further, our results showed a strong positive effect of photo-celebrity congruence on both photo attitudes and purchase intentions. The importance of a match between the celebrity and the product has been shown in previous studies, and our findings show that the importance of congruence also applies in the context of Instagram and to the style of the photo, rather than just the product. Hence, in order to achieve the communication goals and also to address the right stakeholders, organizations need to select the celebrities they work with carefully and ensure that the sponsored photos and messages fit the celebrity's usual 
style. This is also an important implication for the celebrities, who engage in strategic consideration in their own self-presentation and in their staged performance of authenticity (cf. Hou, 2018).

All in all, our findings highlight that the strategic planning of influencer relationships should account for the type of the celebrity and the match between the celebrity profile and the content he or she produces. Authenticity in the celebrity profile should be highlighted more than the person's attractiveness. Further, our findings show that sponsored photos were less favorably perceived than non-sponsored photos. Therefore, celebrity endorsement and influencer collaboration are not shortcuts to effective communication, and strategic planning when cooperating with social media celebrities is of critical importance.

\section{References}

Abidin, C. (2015). Communicative intimacies: Influencers and perceived interconnectedness. Ada: A Journal of Gender, New Media, and Technology, 8.

Abidin, C., \& Ots, M. (2016). Influencers tell all? Unravelling authenticity and credibility in a brand scandal. In M. Edström, A. T. Kenyon \& E.-M. Svensson (Eds.), Blurring the Lines: Market-Driven and Democracy-Driven Freedom of Expression (pp. 153-161). Gothenburg: Nordicom.

Audrezet, A., De Kerviler, G., \& Moulard, J. G. (2018). Authenticity under threat: When social media influencers need to go beyond self-presentation. Journal of Business Research, in press. https://doi.org/10.1016/j.jbusres.2018.07.008

Aula, P., \& Heinonen, J. (2016). The Reputable Firm: How Digitalization of Communication Is Revolutionizing Reputation Management. Cham: Springer. 
Beverland, M., \& Luxton, S. (2005). Managing integrated marketing communication (IMC) through strategic decoupling: How luxury wine firms retain brand leadership while appearing to be wedded to the past. Journal of Advertising, 34(4), 103-116.

Boerman, S. C., Willemsen, L. M., \& Van Der Aa, E. P. (2017). "This post is sponsored”: Effects of sponsorship disclosure on persuasion knowledge and electronic word of mouth in the context of Facebook. Journal of Interactive Marketing, 38, 82-92.

Borchers, N. S. (2016). Crossing the borders: A theory of hybrid advertising formats. In J. F. Hamilton, R. Bodle, \& E. Korin (Eds.), Explorations in Critical Studies of Advertising (pp. 205-217). New York: Routledge.

Brown, S., Kozinets, R. V., \& Sherry, J. F. Jr. (2003). Teaching old brands new tricks: retro branding and the revival of brand meaning. Journal of Marketing, 67(3), 19-33.

Cain, R. M. (2011). Embedded advertising on television: Disclosure, deception, and free speech rights. Journal of Public Policy \& Marketing, 30(2), 226-238.

De Cannière, M. H., De Pelsmacker, P., \& Geuens, M. (2009). Relationship quality and the theory of planned behavior models of behavioral intentions and purchase behavior. Journal of Business Research, 62(1), 82-92.

Chaffey, D. (2017, November 23). Global social media statistics summary 2017. Smart Insights. Retrieved from: http://www.smartinsights.com/social-mediamarketing/social-media-strategy/new-global-social-media-research/

Chaiken, S. (1979). Communicator physical attractiveness and persuasion. Journal of Personality and Social Psychology, 37(8), 1387.

Cheung, C. M., \& Thadani, D. R. (2012). The impact of electronic word-of-mouth communication: A literature analysis and integrative model. Decision support systems, 54(1), 461-470. 
Colliander, J., \& Erlandsson, S. (2015). The blog and the bountiful: Exploring the effects of disguised product placement on blogs that are revealed by a third party. Journal of Marketing Communications, 21(2), 110-124.

Curran, J. (2012). Reinterpreting the Internet. In Curran, J., Fenton, N., \& Freedman, D. (Eds.). Misunderstanding the internet (pp. 3-33). New York: Routledge.

Dekker, K., \& van Reijmersdal, E. A. (2013). Disclosing celebrity endorsement in a television program to mitigate persuasion: How disclosure type and celebrity credibility interact. Journal of Promotion Management, 19(2), 224-240.

Deshpandé, R., \& Stayman, D. M. (1994). A tale of two cities: Distinctiveness theory and advertising effectiveness. Journal of Marketing Research, 31(1), 57-64.

Djafarova, E., \& Rushworth, C. (2017). Exploring the credibility of online celebrities' Instagram profiles in influencing the purchase decisions of young female users. Computers in Human Behavior, 68, 1-7.

Djafarova, E., \& Trofimenko, O. (2018). "Instafamous" - credibility and self-presentation of micro-celebrities on social media. Information, Communication \& Society, doi:10.1080/1369118X.2018.1438491

Elberse, A., \& Verleun, J. (2012). The economic value of celebrity endorsements. Journal of Advertising Research, 52(2), 149-165.

Erdogan, B. Z. (1999). Celebrity endorsement: A literature review. Journal of Marketing Management, 15(4), 291-314.

Erkan, I., \& Evans, C. (2016). The influence of eWOM in social media on consumers' purchase intentions: An extended approach to information adoption. Computers in Human Behavior, 61, 47-55.

Evans, R. B. (1988). Production and Creativity in Advertising. London: Pitman Publishing. 
Fitch, K. (2017). Seeing 'the unseen hand': Celebrity, promotion and public relations. Public Relations Inquiry, 6(2), 157-169.

Fritz, K., Schoenmueller, V., \& Bruhn, M. (2017). Authenticity in branding - exploring antecedents and consequences of brand authenticity. European Journal of Marketing, 51(2), 324-348.

Giles, D. C. (2017). How do fan and celebrity identities become established on Twitter? A study of 'social media natives' and their followers. Celebrity Studies, 1-16.

Gilmore, J. H., \& Pine, B. J. (2007). Authenticity: What Consumers Really Want. Boston: Harvard Business Press.

Gong, W., \& Li, X. (2017). Engaging fans on microblog: the synthetic influence of parasocial interaction and source characteristics on celebrity endorsement. Psychology and Marketing, 34(7), 720-732.

Grayson, K., \& Martinec, R. (2004). Consumer perceptions of iconicity and indexicality and their influence on assessments of authentic market offerings. Journal of Consumer Research, 31(2), 296-312.

Gupta, P. B., \& Gould, S. J. (1997). Consumers' perceptions of the ethics and acceptability of product placements in movies: Product category and individual differences. Journal of Current Issues \& Research in Advertising, 19(1), 37-50.

Hair, J. F., Anderson, R. E., Tatham, R. L. \& Black, W. C. (1998). Multivariate Data Analysis (5th ed.). New Jersey: Prentice Hall.

Hallahan, K., Holtzhausen, D., Van Ruler, B., Verčič, D., \& Sriramesh, K. (2007). Defining strategic communication. International Journal of Strategic Communication, 1(1), 335. 
Hartmans, A. (2018). The 50 most followed Instagram accounts in 2018. Business Insider, 31.12.2018. Retrieved from: https://nordic.businessinsider.com/instagram-top-50people?r=US\&IR=T [Accessed Feb 21, 2019]

Hou, M. (2018). Social media celebrity and the institutionalization of YouTube.

Convergence: The International Journal of Research into New Media Technologies, $1-20$.

Hovland, C. I., Janis, I. L., \& Kelley, H. H. (1953). Communication and Persuasion. New Haven, CT: Yale University Press.

Hsu, C. K., \& McDonald, D. (2002). An examination on multiple celebrity endorsers in advertising. Journal of Product \& Brand Management, 11(1), 19-29.

Ilicic, J., \& Webster, C. M. (2016). Being true to oneself: Investigating celebrity brand authenticity. Psychology and Marketing, 33(6), 410-420.

Jin, S. V. (2018). “Celebrity 2.0 and beyond!” Effects of Facebook profile sources on social networking advertising. Computers in Human Behavior, 79, 154-168.

Jin, S. A. A., \& Phua, J. (2014). Following celebrities' tweets about brands: The impact of Twitter-based electronic word-of-mouth on consumers' source credibility perception, buying intention, and social identification with celebrities. Journal of Advertising, 43(2), 181-195.

Kahle, L. R., \& Homer, P. M. (1985). Physical attractiveness of the celebrity endorser: A social adaptation perspective. Journal of Consumer Research, 11(4), 954-961.

Kamen, J. M., Azhari, A. C., \& Kragh, J. R. (1975). What a spokesman does for a sponsor. Journal of Advertising Research, 15(2), 17-24.

Kamins, M. A. (1990). An investigation into the 'match-up' hypothesis in celebrity advertising: When beauty may be only skin deep. Journal of Advertising, 19(1), 4-13. 
Kapitan, S., \& Silvera, D. H. (2016). From digital media influencers to celebrity endorsers: Attributions drive endorser effectiveness. Marketing Letters, 27(3), 553-567.

Keel, A., \& Nataraajan, R. (2012). Celebrity endorsements and beyond: New avenues for celebrity branding. Psychology \& Marketing, 29(9), 690-703.

Khamis, S., Ang, L., \& Welling, R. (2017). Self-branding, 'micro-celebrity' and the rise of social media influencers. Celebrity Studies, 8(2), 191-208.

Kim, Y. J., \& Na, J. H. (2007). Effects of celebrity athlete endorsement on attitude towards the product: The role of credibility, attractiveness and the concept of congruence. International Journal of Sports Marketing and Sponsorship, 8(4), 23-33.

Knoll, J., \& Matthes, J. (2017). The effectiveness of celebrity endorsements: a meta-analysis. Journal of the Academy of Marketing Science, 45(1), 55-75.

Labrecque, L. I. (2014). Fostering consumer-brand relationships in social media environments: The role of parasocial interaction. Journal of Interactive Marketing, 28(2), 134-148.

Labrecque, L. I., Markos, E., \& Milne, G. R. (2011). Online personal branding: Processes, challenges, and implications. Journal of Interactive Marketing, 25(1), 37-50.

Lu, L.-C., Chang, W.-P., \& Chang, H.-H. (2014). Consumer attitudes toward blogger's sponsored recommendations and purchase intention: The effect of sponsorship type, product type, and brand awareness. Computers in Human Behavior, 34, 258-266.

Macnamara, J., \& Zerfass, A. (2012). Social media communication in organizations: The challenges of balancing openness, strategy, and management. International Journal of Strategic Communication, 6(4), 287-308.

Malhotra, N., Birks, D., \& Wills, P. (2012). Marketing Research: An Applied Approach (4th ed.). Essex: Pearson Education Limited. 
Marwick, A. E. (2015). Instafame: Luxury selfies in the attention economy. Public Culture, 27(1), 137-160.

Marwick, A. E. (2013). Status Update: Celebrity, Publicity, and Branding in the Social Media Age. Yale University Press.

Mathur, L. K., Mathur, I., \& Rangan, N. (1997). The wealth effects associated with a celebrity endorser: The Michael Jordan phenomenon. Journal of Advertising Research, 37(3), 67-74.

McCormick, K. (2016). Celebrity endorsements: Influence of a product-endorser match on millennials' attitudes and purchase intentions. Journal of Retailing and Consumer Services, 32, 39-45.

McCracken, G. (1989). Who is the celebrity endorser? Cultural foundations of the endorsement process. Journal of Consumer Research, 16(3), 310-321.

McLeod, K. (1999). Authenticity within hip-hop and other cultures threatened with assimilation. Journal of Communication, 49(4), 134-150.

Molleda, J. C., \& Roberts, M. (2008). The value of "authenticity" in "glocal" strategic communication: The new Juan Valdez campaign. International Journal of Strategic Communication, 2(3), 154-174.

Molleda, J. C. (2010). Authenticity and the construct's dimensions in public relations and communication research. Journal of Communication Management, 14(3), 223-236.

Moulard, J. G., Garrity, C. P., \& Rice, D. H. (2015). What makes a human brand authentic? Identifying the antecedents of celebrity authenticity. Psychology and Marketing, $32(2)$,

Nebenzahl, I. D., \& Secunda, E. (1993). Consumers' attitudes toward product placement in movies. International Journal of Advertising, 12(1), 1-11. 
Nelson, M. R., Keum, H. \& Yaros, R. A. (2004). Advertainment or adcreep game players' attitudes toward advertising and product placements in computer games. Journal of Interactive Advertising, 5(1), 3-21.

Ohanian, R. (1990). Construction and validation of a scale to measure celebrity endorsers' perceived expertise, trustworthiness, and attractiveness. Journal of Advertising, 19(3), $39-52$.

Ohanian, R. (1991). The impact of celebrity spokespersons' perceived image on consumers' intention to purchase. Journal of Advertising Research, 31(1), 46-54.

Omnicore (2017). Instagram by the numbers: Stats, demographics \& fun facts. Retrieved from https://www.omnicoreagency.com/instagram-statistics/

Park, S., \& Cho, M. (2015). Celebrity endorsement for nonprofit organizations: The role of celebrity motive attribution and spontaneous judgment of celebrity-cause incongruence. Journal of Promotion Management, 21(2), 224-245.

Phua, J., Lin, J. S., \& Lim, D. J. (2018). Understanding consumer engagement with celebrityendorsed e-cigarette advertising on Instagram. Computers in Human Behavior, 84, 93-102.

Pornpitakpan, C. (2004). The effect of celebrity endorsers' perceived credibility on product purchase intention: The case of Singaporeans. Journal of International Consumer Marketing, 16(2), 55-74.

Roettgers, J. (2016, August 22). Kardashians in trouble over paid product endorsements on Instagram. Variety. Retrieved from http://variety.com/2016/digital/news/kardashiansinstagram-paid-ads-product-placements-1201842072/

Roy, S. (2016). Meaning transfer in celebrity endorsements: an explanation using metaphors. Journal of Marketing Communications, 24(8), 843-862. 
Van Ruler, B. (2018). Communication theory: An underrated pillar on which strategic communication rests. International Journal of Strategic Communication, 12(4), 367381.

Schallehn, M., Burmann, C., \& Riley, N. (2014). Brand authenticity: model development and empirical testing. Journal of Product \& Brand Management, 23(3), 192-199.

Senft, T.M. (2008). Camgirls: celebrity and community in the age of social networks. New York: Peter Lang.

Silvera, D. H., \& Austad, B. (2004). Factors predicting the effectiveness of celebrity endorsement advertisements. European Journal of Marketing, 38(11/12), 1509-1526.

Spears, N., \& Singh, S. N. (2004). Measuring attitude toward the brand and purchase intentions. Journal of Current Issues \& Research in Advertising, 26(2), 53-66.

Sudha, M., \& Sheena, K. (2017). Impact of influencers in consumer decision process: the fashion industry. SCMS Journal of Indian Management, 14(3), 14-30.

Thomas, S. (2014). Celebrity in the "Twitterverse": history, authenticity and the multiplicity of stardom Situating the "newness" of Twitter. Celebrity Studies, 5(3), 242-255.

Till, B. D., \& M. Busler (1998). Matching products with endorsers: Attractiveness versus expertise. Journal of Consumer Marketing, 15(6), 576-586.

Tolson, A. (2013). A new authenticity? Communicative practice on YouTube. In L. Chouliaraki (Ed.), Self-Mediation - New Media, Citizenship and Civil Selves (pp. 93106). London: Routledge.

Tutaj, K., \& van Reijmersdal, E. A. (2012). Effects of online advertising format and persuasion knowledge on audience reactions. Journal of Marketing Communications, $18(1), 5-18$.

Vannini, P., \& Franzese, A. (2008). The authenticity of self: Conceptualization, personal experience, and practice. Sociology Compass, 2(5), 1621-1637. 
De Veirman, M., Cauberghe, V., \& Hudders, L. (2017). Marketing through Instagram influencers: The impact of number of followers and product divergence on brand attitude. International Journal of Advertising, 36(5), 1-31.

Verhellen, Y., Dens, N., \& De Pelsmacker, P. (2013). Consumer responses to brands placed in Youtube movies: the effect of prominence and celebrity endorser expertise. Journal of Electronic Commerce Research, 14(4), 287-303.

De Vries, L., Gensler, S. \& Leeflang, P. S. H. (2012). Popularity of brand posts on brand fan pages: An investigation of the effects of social media marketing. Journal of Interactive Marketing, 26(2), 83-91.

Wang, Y., Qiao, F., \& Peng, W. (2015). Is the size or the valence of proactive engagement associated with purchase intention? A case study of branded blogs of Starbucks. International Journal of Strategic Communication, 9(3), 197-216.

Zerfass, A., Verčič, D., Nothhaft, H., \& Werder, K. P. (2018). Strategic communication: Defining the field and its contribution to research and practice. International Journal of Strategic Communication, 12(4), 487-505. 
Table 1

Survey Constructs and Items

\begin{tabular}{|c|c|c|c|c|c|c|c|}
\hline \multirow[b]{2}{*}{ Construct } & \multirow[b]{2}{*}{ Item } & \multicolumn{2}{|c|}{ Item } & \multicolumn{3}{|c|}{ Scale } & \\
\hline & & $M$ & $S D$ & $M$ & $S D$ & Cronbach's & Source \\
\hline
\end{tabular}

Questions about the celebrity in general. "I think this person is..."

$\begin{array}{llllllll}\text { Authenticity } & \text { Genuine. } & 5.12 & 1.39 & 5.18 & 1.18 & .926 & \text { Vannini \& Franzese, } \\ & \text { Honest. } & 5.21 & 1.32 & & & & \text { 2008; Ilicic \& } \\ & \text { Sincere. } & 5.21 & 1.08 & & & & \text { Webster, 2016 } \\ \text { Attractiveness } & \text { Attractive. } & 5.64 & 1.03 & 5.80 & .99 & .942 & \text { Ohanian, 1990 } \\ & \text { Stylish. } & 5.97 & 1.02 & & & & \end{array}$

Questions about each of the celebrity's nine latest photos.

\begin{tabular}{|c|c|c|c|c|c|c|c|}
\hline Photo-celebrity & This photo fits well & 5.76 & 1.38 & 5.64 & 1.31 & .850 & Kim \& Na, 2007 \\
\hline congruence & with this Instagram & & & & & & \\
\hline & account's overall & & & & & & \\
\hline & style. & & & & & & \\
\hline & This person is loyal to & 5.53 & 1.43 & & & & \\
\hline & his/her style in this & & & & & & \\
\hline & photo. & & & & & & \\
\hline Photo attitude & I like this photo. & 5.53 & 1.52 & 5.31 & 1.49 & .884 & Silvera \& Austad, \\
\hline & This photo is & 5.09 & 1.64 & & & & 2004 \\
\hline & interesting. & & & & & & \\
\hline Purchase & I get ideas for new & 3.92 & 1.95 & 4.29 & 1.70 & .853 & Erkan \& Evans, \\
\hline intention & purchases from this & & & & & & 2016 \\
\hline & photo. & & & & & & \\
\hline & This photo inspires & 4.59 & 1.84 & & & & \\
\hline & purchases. & & & & & & \\
\hline & I could consider & 4.38 & 2.00 & & & & \\
\hline & buying something I & & & & & & \\
\hline & see in the picture. & & & & & & \\
\hline
\end{tabular}


Table 2

Hierarchical Multiple Regression Results, Photo Attitude

\begin{tabular}{lcccc}
\hline Independent variables & \multicolumn{4}{c}{ DV: Photo attitude (all photo evaluations, N = 5119) } \\
\cline { 2 - 5 } & $\beta$ & $t$ & $\Delta F$ & $\Delta R^{2}$ \\
\hline Step 1: Control variables & & & & \\
Constant & & $40.723^{* *}$ & $24.062^{* *}$ & .005 \\
Likes & .068 & $4.905^{* *}$ & &
\end{tabular}

Step 2: Celebrity-related variables

\begin{tabular}{|c|c|c|c|}
\hline Constant & & $6.004 * *$ & $329.191 * *$ \\
\hline Likes & .068 & $5.067^{* *}$ & \\
\hline Authenticity & 227 & $15.470^{* *}$ & \\
\hline Attractiveness & 240 & $16.356^{* *}$ & \\
\hline Social media influencer & .029 & $2.182 *$ & \\
\hline
\end{tabular}

Step 3: Photo-related variables

\begin{tabular}{|c|c|c|c|}
\hline Constant & & -.870 & $1091.871 * *$ \\
\hline Likes & .020 & 1.781 & \\
\hline Authenticity & .122 & $9.813^{* *}$ & \\
\hline Attractiveness & .123 & $9.778^{* *}$ & \\
\hline Social media influencer & .001 & .106 & \\
\hline Photo-celebrity congruence & .533 & $46.456^{* *}$ & \\
\hline Photo sponsorship & -.056 & $-5.193 * *$ & \\
\hline
\end{tabular}

Overall $R^{2}=.415$

Adjusted $R^{2}=.415$

Note. ${ }^{*} p<.05, * * p<.01$ 
Table 3

Hierarchical Multiple Regression Results, Purchase Intention

\begin{tabular}{|c|c|c|c|c|}
\hline \multirow{3}{*}{ Independent variables } & \multicolumn{4}{|c|}{ DV: Purchase intention (sponsored-photo } \\
\hline & \multicolumn{4}{|c|}{ evaluations, $\mathrm{N}=1312$ ) } \\
\hline & $\beta$ & $t$ & $\Delta F$ & $\Delta R^{2}$ \\
\hline \multicolumn{5}{|l|}{ Step 1: Control variables } \\
\hline Constant & & $18.986 * *$ & 3.165 & .002 \\
\hline Likes & -.049 & -1.799 & & \\
\hline \multicolumn{5}{|l|}{ Step 2: Celebrity-related variables } \\
\hline Constant & & 1.166 & $57.603 * *$ & .116 \\
\hline Likes & .009 & .300 & & \\
\hline Authenticity & .254 & $8.599 * *$ & & \\
\hline Attractiveness & .118 & $3.969 * *$ & & \\
\hline Social media influencer & .136 & $4.308 * *$ & & \\
\hline \multicolumn{5}{|l|}{ Step 3: Photo-related variables } \\
\hline Constant & & -1.696 & $165.310 * *$ & .178 \\
\hline Likes & -.011 & -.382 & & \\
\hline Authenticity & .162 & $6.030 * *$ & & \\
\hline Attractiveness & .012 & .451 & & \\
\hline Social media influencer & .088 & $3.039 * *$ & & \\
\hline Photo-celebrity congruence & .458 & $17.948 * *$ & & \\
\hline Sponsor disclosure & .015 & .601 & & \\
\hline \multicolumn{5}{|c|}{ Overall $R^{2}=.297$} \\
\hline & Adjust & $2^{2}=.294$ & & \\
\hline
\end{tabular}

Note. ${ }^{*} p<.05, * * p<.01$ 